\title{
Nicolau Nazo, Jurista, Professor Emérito e Jornalista.
}

\section{A Redação}

A memória do Professor emérito Nicolau Nazo, falecido em 1974, foi reverenciada no meio jurídico e político do país, através de várias homenagens póstumas.

Em São Paulo, pelo Egrégio Tribunal de Justiça, pelos Tribunais de Alçada Civil, do Criminal e de Contas, pela Assembléia Legislativa e Municipal, e no Senado Federal, em Brasília.

Os oradores ressaltaram, na figura simples e afável do advogado militante, jornalista e cultor do Direito, a vocação do educador preocupado em transmitir a seus discípulos uma visão sempre atualizada do Direito, ao ministrar Direito Civil, Comercial, Social e Internacional Privado.

Sua obra foi relembrada pelas matérias expostas em cursos os mais diversos, pelos pareceres, artigos e monografias publicados em revistas especializadas que continuam servindo a estudantes e estudiosos do Direito; salientou-se a tese defendida, em doutoramento, há mais de quarenta anos, Proteção das Minorias nas Sociedades Anônimas, tema que, nesta clécada, tem motivado discussões sobre o projeto de reforma da Lei das Sociedades Anônimas.

O Instituto de Direito Social, sob a presidência do Professor Antônio Cesarino Júnior, também, homenageou seu conselheiro fundador e titular da cadeira número 10 , em sessão solene realizada aos 28 de abril do corrente ano, quando inaugurou-lhe o retrato a óleo na sala principal. 
Falou na ocasião o professor Dr. Moacyr Lobo da Costa, enaltecendo a personalidade do homenageado, em discurso publicado a seguir.

\section{Discurso de Moacyr Lobo da Costa.}

No momento em que o Instituto de Direito Social procede à inauguração do retrato de Nicolau Nazo, na galeria de seus maiores, acodem-me, como intérprete dos sentimentos que inspiraram esta solenidade, as palavras candentes de Ruy Barbosa a propósito de bustos e estátuas:

"Bem aventurados os que a si mesmos se estatuaram em atos memoráveis, e, sem deixarem os retratos à posteridade, esquecediça ou desdenhosa, vivem a sua vida póstuma desinteressadamente pelos benefícios que lhe herdaram"

De Nicolau Nazo, cujo semblante a arte fotográfica nos permite hoje rever e recordar, pode-se dizer, sem favor nem exagero, ter alcançado esse estado de bem aventurança, por ter esculpido em vida sua própria estátua.

A morte, pondo termo à vida de seu corpo, não lhe extinguiu a do espírito, que perdura na vivência do seu grande legado.

Tendo percorrido com dignidade sem par diferentes caminhos, no desempenho de múltiplas atividades profissionais e sociais, uma sobre todas marcou sua existência, com singular relevo, emprestando-lhe o traço característico e inconfundível: o magistério.

No jornalista, que se alçou dos bancos da redaçāo para se tornar professor de jornalismo; no advogado, que trocou os embates do fôro pela disputa dos prélios acadêmicos e se sagrou catedrático nas duas principais Faculdades de Direito de São Paulo; no jurista, cujas obras concorrem para o escla- 
recimento de intrincadas questões de direito civil, de direito internacional privado, de direito comercial ou de direito social, estava ele cumprindo a incoercível vocação para o magistério.

$\mathrm{E}$ foi como professor, vivendo intensamente seu apostolado pedagógico, que ele conquistou a imortalidade.

Ante o insondável mistério da morte e o insolúvel problema da sobrevivência da alma, que os filósofos debatem mas somente a fé aponta uma solução, válida ao menos para os crentes, a filosofia existencialista conclui que somente se salvam do eterno olvido aqueles que assinalaram sua passagem pelo mundo "com atos memoráveis" para usar as palavras de Ruy.

Não é por ser homem que o homem é imortal, mas é por suas obras que ele se imortaliza.

Em sua conceituação existencial a imortalidade não é um dom, mas uma conquista. Não é um atributo do ser humano, mas o modo de ser de alguns homens.

Para exemplificar: dos milhares de trabalhadores anônimos, que gastaram a vida na construção das pirâmides do Egito, não restou vestígio nas páginas da História, que guardou, entretanto, o nome dos faraós que as mandaram erigir.

Quando os meios racionais de conhecimento não nos permitem devassar o mistério de uma possível vida extra-terrena, nosssa curiosidade há-de contentar-se com os dados da História para elaborar o conceito agnóstico da imortalidade.

Ser imortal é sobreviver à morte na memória dos pósteros. Sobrevivência alicerçada em atos e obras.

Na história do ensino do direito em nosso país, o professor Nicolau Nazo conquistou a sobrevivência de seu nome, pela exemplar dedicação ao magistério, que honrou com sua ciência e dignificou com seu exemplo. 
O magistério, entre as agruras que não faltam e as alegrias que escasseiam, foi-lhe apostolado em que pôs à prova a serenidade de seu espírito superior.

Mestre, não só dos discípulos que escutaram suas lições nos bancos acadêmicos, mas de quantos se abeberam de seus ensinamentos nos livros, nos artigos, nos pareceres, que legou à ciência do direito, sobretudo, Mestre pelo exemplo, que foi a maior de suas lições.

Exemplo de como esculpir laboriosa e pacientemente a estátua de um professor, com abnegação e perseverança, seriedade e entusiasmo, sem alardes nem ruídos, rejeitando o efêmero para se fixar no eterno.

Seu nome está intimamente ligado à vida deste Sodalício, desde sua fundação, ao qual emprestou decidido apoio, colaborando na missão de difundir os princípios basilares do Direito Social, mediante as conferências que proferiu e os cursos de aperfeiçoamento que ministrou sob o patrocínio deste Instituto.

A inauguração de seu retrato na sala de reuniões é um ato social de profunda significação. E a maneira de manter presente seu semblante, ao lado dos companheiros que como ele honraram esta instituição, quando não podemos mais desfrutar de seu convívio. Te-lo sob nosso olhar, para inspirar nossas deliberaçães, quando não nos é mais dado ouvir seus conselhos.

Para que se não perca a lembrança da figura do homem ái está seu retrato. O que lhe assegura a vida póstuma, porém, é o tesouro de ensinamentos que nos legou.

\section{Discurso de Agradecimento de Georgette Nacarato Nazo.}

Exmo. Sr. Prof. Dr. Antonio Ferreira Cesarino Júnior, Presidente do Conselho do Instituto de Direito Social, Ilmo. 
Sr. Capitão Orlando Aurélio Santos, representantes de Sua Excia. o Vice-Governador de São Paulo, Prof. Dr. Manoel Gonçalves Ferreira Filho, Exmo. Sr. Dr. José Cardoso Filho, DD. Presidente do 2. ${ }^{\circ}$ Tribunal de Alçada Civil do Estado de São Paulo, Ilmo. Sr. Chefe do Gabinete, representante do Dr. Prestes Barra, DD. Presidente do Tribunal de Alçada Criminal de São Paulo, Exmo. Sr. Geraldo Camargo Vidigal, Presidente do Instituto dos Advogados de São Paulo, autoridades presentes, Srs. Conselheiros do Instituto de Direito Social, queridos amigos que nos prestigiam nesta solenidade, nosso grande e querido amigo Moacyr Lobo da Costa, intérprete das homenagens que hoje são prestadas a Nicolau NAzo, ex-Conselheiro-Fundador, titular da cadeira n. ${ }^{\circ} 10$ nessa prestigiosa entidade:

Cumpre-me em nome da Família de Nicolau Nazo uma tarefa tocante e profundamente difícil de, em nome de todos os seus familiares, agradecer tão honrosa deferência.

Depois de ouvir, com muita atenção e comovida até as lágrimas, as brilhantes palavras do orador designado pelo Instituto de Direito Social, para reverenciar a memória de seu ex-Conselheiro-Fundador desta Casa, traçando-lhe o perfil, revelando sua prolífera atuação, quer no campo das letras, do jornalismo, na advocacia militante e, particularmente no magistério em setores diversos, para nós, de sua família, resta relembrar sua dedicação às artes, no campo da história da música e do teatro, na técnica de imprensa, demonstrando, neste agradecimento, um outro ângulo de sua figura, marcantemente, humana.

Se, sua origem humilde obrigou-o, desde os nove anos de idade, a aprender a trabalhar para o sustento da mãe e de cluas irmãs menores, quando lhes veio a faltar o chefe da família, encontrou no trabalho a extrema necessidade de se dedicar aos estudos, para que, um dia, encontrasse melhores condiçōes de vida. 
Sua luta foi árdua e pertinaz.

Sua coragem, inaudita e sem esmorecimentos.

Dormia num banco da redação dos jornais, para não perder a hora das aulas na Academia do Largo de São Francisco.

Vencendo no jornalismo, na flor da idade, sendo guindado, em curto prazo, a funções de direção e supervisão, nos primórdios do Jornal do Comércio e do Correio Paulistano, daí passou para O Estado de São Paulo e para A Gazeta, sendo que, nos últimos tempos, abandonando a crítica teatral, dedicou-se à crítica jurídica.

Se relembrarmos os tempos em que, no "Conservatório Dramático e Musical de São Paulo", ministrou História da Arte e do Teatro, bem como diç̧ão, encontraremos uma personalidade famosa que se destacou no Teatro Brasileiro: sua discípula Olga Navarro.

Mas, perdoem-me os que aqui me ouvem, se, ao em vez de lhes falar do cultor das letras e do direito, veja-me na contingência de trazer a público a personalidade de "Paizinho": aquela criatura doce, afável, incapaz de sentimento de rancor ou de menosprezo pelos semelhantes. Dotado de uma memória privilegiada, estava sempre a par de tudo, abrindo-se num diálogo franco, sincero, sem rebuços, com uma visão global e atualizada a respeito das transformações de nossa época, até os últimos instantes de sua vida.

A simplicidade e a humildade do homenageado desta noite, encontrou na companheira que batalhou a seu lado, no dia a dia, por 43 anos de um amor imenso, reflexo da compreensão autêntica e da integral comunhão de almas, um estímulo e um esteio para as suas lutas.

Mesmo quando ela desapareceu de nosso convívio, paizinho, ministrando suas aulas de Direito Civil, transmitia aos discípulos a sua concepção de casamento, nestes termos: 
"CASAMENTO é a congregação de sentimentos entre marido e mulher, é a integração de ambos numa relação íntima - física e moral - oriunda de uma permanente comunhão de vida, que produz, pela sua vontade própria, a transformação do egoismo individual e social, numa fonte de purificação do indivíduo".

"Só a união que nasce e permanece no amor entre os cônjuges é que torna o casamento indestrutível"

Realmente, sua vida conjugal foi o corolário destas concepções, conseguindo transferir para suas duas filhas e, depois, para os dois netos, este exemplo belíssimo de comunhão e entrelaçamento de almas: foram dois, numa só carne.

Jamais usou da "patriapotestas".

Foi o chefe de família dedicado e cônscio de seus deveres, seguindo a lição de São Paulo aos Efésios, valorizando a mulher, deixando para ela o desempenho de suas reais e verdadeiras atribuições dentro do lar, administrando-o com liberdade, como tão bem soube fazê-lo.

Juntos, conseguiram a perfeita harmonia de personalidades fortes e díspares que compunham essa sociedade familial.

Da mesma forma que souberam orientar suas duas fiİhas, mostrando-lhes o valor do respeito à hierarquia e aos poderes constituídos, desdobraram-se junto aos netos, para que estes também se conscientizassem da importância de tais valores.

E, paizinho, foi mais além.

Sobre qualquer assunto que se lhe pedisse um informe, um esclarecimento, sabia conversar em termos claros, accessí- 
veis à idade do interlocutor, percebendo-se o seu desejo de servir, de ser útil à sociedade em que vivia.

Dele, só recebemos beneces.

Dele, guardamos uma lembrança e uma saudade imensa.

Falta-nos, agora, aqueles "tête-a-tête" informais, mesmo quando, divergindo de seus pontos de vista, não impunha suas opiniões, o que merece de nós termos a consciência de que vivemos, lado a lado, de um sábio.

$\mathrm{E}$, por esta razão, acreditamos que, agradecendo, com o coração embargado pela emoção, a homenagem que lhe presta o Instituto de Direito Social, é com infinda saudade, que ousamos transcrever um provérbio chinês, que se ajusta, radicalmente, a esta maravilhosa figura humana:

"Aquele que não sabe,

e não sabe, que não sabe,

é um tonto: FUja dele.

Aquele que não sabe,

e que sabe, que não sabe,

é humilde: ENSINA-LHE.

Aquele que sabe,

e não sabe, que sabe,

está dormindo: DESPERTA-O.

Aquele que sabe,

e sabe, que sabe,

é SÁBIO: SIGA-O."

Humilde no seu saber, ENSINOU a muitos.

DESPERTOU em seus companheiros de trabalho e nas centenas de discípulos que teve, a importância do aprimoramento da cultura para a grandeza do ser humano e o aperfeiçoamento da sociedáde e do País. 
Senhores:

A este sábio é que nós, de sua família, tentaremos seguir, agradecendo-lhe por tão significativo legado.

Paizinho: Você foi um homem feliz!

Cumpriu a parábola: recebeu a sua cota de talentos e, na missão que desenvolveu nesta terra, onde você se encontrar, já deve ter prestado suas contas a Deus, com entrega positiva, da devolução em dobro do que por ÊLE lhe foi ofertado. 